\title{
The Communal Land Ownership Conflict between Lewobunga and Lewonara Villages, East Nusa Tenggara, Indonesia
}

\author{
Muhamad Fadhil Nurdin \\ Universitas Padjadjaran, Bandung, Indonesia \\ Email: mfadhilunpad@hotmail.com
}

http://dx.doi.org/10.18415/ijmmu.v6i1.496

\begin{abstract}
In the context of conflict on communal land ownership between Lewobunga and Lewonara Villages, in East Nusa Tenggara, Indonesia this article found that not all the western sociological theories are relevant to analyze social conflicts in Indonesia which culturally diverse in the both villages. Generally, this article attempts to examine two main issues. First, to examine the existing sociological theories in relations with the local communal land ownership in Indonesia. Second, to examine the sociological theories in the context of communal land ownership conflict between Lewonara and Lewobunga villages. This is qualitative research with Hermeneutic Reproductive approach and the result of this article obtained from the fieldwork data.
\end{abstract}

Keywords: Sociology of Conflict; Rural; Communal Land; Tribal War

\section{Introduction}

Social interaction in social life can lead to cooperation and attachment. However, on the other hand, it can also cause conflict due to clash of interest among actors and groups. The source of conflict generally generated by such factors as cultural differences, characters, and certain norms in a social system. In other words, a conflict is a dissociative form of social interaction (Soekanto., 2009).

Indonesia that consists of more than 1,340 ethnic groups have various traditional cultures. These tribes have own beliefs, norms, and customary laws, which are traditionally and strongly be embraced by the people. The people of Flores Timur along with some uniqueness classified into an ethnic group called as Lamaholot ethnic. The Lamaholot ethnic group occupies mainly the eastern part of the island of Flores, Solor Island, Adonara Island, and Lembata Island. This ethnicity divided into various tribes scattered across the villages in these islands. Under customary law prevailing in Lamaholot, tribal problems are often traditionally resolved through tribal wars. In Lewobunga and Lewonara villages, the communal land conflicts that resulted in tribal war continue to occur until recently. However, other villages in East Flores the tribal wars no longer outbreak.

In the meantime, local governments enforce criminal laws and other formal meetings especially with religious leaders, security apparatus, and community leaders to overcome the conflict. Nevertheless, 
all the local government initiatives have failed to end the conflict following the occurrence of two major tribal wars over five years involving Lewobunga and Lewonara villages during 2012-2015. In the local term, the conflict called as Gening Nura Newa means, "to seize communal land" to define how seriously the communal conflict between the two villages. The primary question of this article is to what extent the western sociological theories relevant to analyze and offer solution regarding communal conflict on land ownership between the Lewobunga and Lewonara villages in East Nusa Tenggara, Indonesia.

\section{Conflict and Sociology: A Review}

In the early development of sociology, conceptually conflicts were limited to conservative reactions to The Enlightenment Era and The French Revolution (1789-1799). The Enlightenment period begins with the development of enlightenment ideas that made people can understand the universe rationally and empirically. All enlightened philosophers such as Immanuel Kant, Jacques Rousseau, Charles Montesquieu, etc., were rejected all forms of authoritarian traditional powers. The ideas of Enlightenment era became one of the most important factors in the French Revolution. Sociologically, the philosophers of the Enlightenment wanted to create a better and more rational world (Ritzer., 2010). The reaction of resistance to the philosophy of enlightenment was carried out by August Comte through the philosophy of positivism (Ritzer., 2010). On one hand, Comte emphasizes the aspect of rationality in sociology. On the other hand, contradictory and conservatively, he wants to create social laws in sociology as an authority that creates the order of the social world. The main objective of Comte's ideas is to avoid conflicts as the conflict in the French Revolution. To be sure, Comte is very conservative because of his rationality ideas of social order through sociology.

The concept of conflict is fundamentally appeared implicitly in the Emile Durkheim's works that pays attention on non-material social facts especially norms and values. According to Ritzer (2010), there are four types of non-material social facts refers to the Durkheim's thoughts, namely morality, collective conscience, collective representation, and social flow. Thompson (2002) reveals that Durkheim approached the theme of conflict with the view that the social world is a system of limited forces (morality) that complement each other to create a balance. Collins (1988) adds that Durkheim makes an important contribution to social stratification in conflict theory, which values and norms define a social class and moral solidarity in conflict-affected groups. The values and norms in a social structure are the basis for establishing social class and the quality of moral unity in groups in a social stratification. In this context, Durkheim ignores the role of the individual to interpret and adhere to values and norms in social interaction. The criticism for Durkheim is that he is too functional because he considers only a social structure capable of meeting the needs of society. He is also often criticized as moralistic, for he directs sociology to decide on "what to do" rather than "what already exists naturally" (Ritzer., 2010). In other words, values and norms in the social structure must refer to the unity of morality shared by all individuals in society. Yet, no matter how the values and norms apply, individuals may engage in actions that violate values and norms, creating an opportunity for conflict.

Meanwhile, conflict according to Karl Marx's concept defined as a class conflict. The term "class conflict" first appeared in Marx and Engels' Communist Manifesto in 1848. Marx described this conflict as the exploitation of the capitalist class of the working class (labor). The owner of capital controls all properties (materials and means of production) used to oppress the working class. This conflict is structural and unavoidable because the owners of capital have perceived the workers as commodities so that workers do not receive a wage that suits their work. Profits (surplus value) are the cause of capital owners to exploit the working class. The state creates rules protecting the owners of capital and repressive against the working class with violence strategy. However, Marx also recognizes that conflicts can occur in other social classes based on ethnicity, religion, race, and gender (Bottomore., 1991, O'Neill., 1985, Collins., 1974, Shaw., 1985, Ritzer., 2010). 
According to Wright (2003: 10), one of the standard arguments about the class analysis of Marxism is that the uniqueness of class relations based on Marx's paradigm is not to provide an absolute view in class conflict, but to understand conflicts in general based on inherent factors rather than other factors that merge easily in a relation. In other words, the inherent factors in relationships are capital, work, wages, working hours, and mastery of means of production. Thus, class conflict in Marxism is the result of unequal social production relations. Critics of Marx's thinking include the failure of the Marxistbased communist state, the lost emancipation, the missing gender dimension, and the economy due to only perceived as production (Ritzer., 2010). However, other sociologists, such as Habermas, Bourdieu, Giddens, Honneth, Lefebvre, Erick Wright, and Wright Mills are tend to develop and criticize against Marx's ideas.

Nonetheless, the Max Weber's overall thought is obviously referring to the social action. He has developed important theories, such as Rationality and Authority theories. It interprets actions in terms of subjective meanings, such as economic action based on the conscious orientation of economic considerations; a Subjective belief that the economic supply is necessary; neither an objective need to create an economic inventory (Ritzer., 2010). For Weber, conflicts occur in social relationships when the actor's actions affect others. He introduces a term namely "peaceful conflict." This peaceful conflict is a "competition" without physical violence. This competitive process legally regulated by authority. It is an inter-individual struggle in the types of social status to gain opportunity and advantage in order to survive. According to Weber (1947), this concept called as "social selection". In other words, conflict is a competition of action which governed by authority.

A comparison between Marx and Weber, according to Collins (1974) states that Weber shows different forms of property ownership conflicts that exist in the division of classes, describes the principles of intercommunication within the organization, then describes the conflict of interest in each field within an organization. Weber extends the meaning of conflict as a struggle (competition) to master resources. Collins calls this the "meaning of emotional production" which is the power of religious institutions connected with the state to convert social classes into group social status, and geographically based communities become ethnic-based communities. Wieviorka (2010: 2) argues that Marx is interested in the ownership of production and the oppression of the working class, while Weber tends to be interested in bureaucracy and rationalization of society. Marx thought that the emancipation of the working class could guarantee the people to overcome the conflict, while Weber was very skeptical on the end of the conflict. Weber often criticized because his theory is likely lacks of critical pertaining constructive change issues (Ritzer., 2010).

The classical sociologist who began to focus on developing conflict theory in his works is George Simmel through a book called Conflict and Web of Group Affiliations (1955). Simmel explains, "Conflict can change groups of interests, organizations, and unity." Paradoxically, it is difficult to imagine conflict as a form of cooperation, regardless of outcome and consequence. Yet, if human interaction is cooperation, then the conflict between human beings is also cooperative (associative). Conflict can also occur due to associative factors, such as jealousy, hatred, etc. Thus, the conflict is present to overcome dualism and to construct uniformity even if one party must lose (1955: 1). He revealed that in a conflict, negative and positive aspects are always integrated. Furthermore, he formulated that homogeneity, heterogeneity, antagonism, hostility, interests, the quality and quantity of group members in the social structure, and cooperation, were able to create integration within the conflict of contradictions (1955). Therefore, Simmel attempted to compile all conflicts, make an integration. In other words, Simmel's argument is too paradox with the realities.

In the 1950s, conflict theories became one of the most important theories in sociology through Lewis Cosser in his book The Function of Social Conflict (1956), and Ralph Dahrendorf through a book entitled Class and Class Conflict in Industrial Society (1957). Cosser seemed to want to unite conflict 
theory and structural functionalism theory in his book. Then, he offers some arguments on conflict that fundamentally still has relationship with Simmel's theory of conflict (Cosser., 1956: 8, Abercombie et. al. 2010). Those arguments are: 1) Conflict unites unified society; 2) Conflict can create an alliance; 3) Conflict makes some unaccounted individuals have roles; 4) Conflict also has communication functions (Ritzer., 2010). He conveyed that conflicts has made to gain respect, status, power, and resources as well as to defeat or injure the opposition parties (Cosser., 1956). Therefore, he wrote sixteen propositions related to conflict function in his book. The important point of the book is that conflict has a function rather than dysfunction, and functions as a tool to adapt and prevent imbalances within groups or communities. The negative functions of conflict must be omitted (Cosser., 1956; Abercrombie et. al. 2010). When criticizing Cosser, Dahrenderof (1957) writes, "Cosser's statement (about the function of social conflict) is a fallacy of the terminology of the theory of community integration." In other words, Cosser, just like Simmel, seems paradox due to it reduces any conflict in conflict into a positive integrity.

Dahrenderof writes several critical assumptions on Marx's thoughts. Those critical assumptions are: i) the term class as a theory can be detached from the antagonistic relationship between the classes of capitalists and the working class; ii) there is an emphasis on the concept of power and power; iii) the contradictory separation between class political conflict and industry, iv) the application of conflict theory is used to analyze contemporary society, and lastly v) this analysis is not done on a wide scale and based on practice (Dahrenderof., 1959). Based on those assumptions, he then examines power and power within the social structure that positions within the social structure have different qualities of power. The power lies not within the person, but in that position and the conflict naturally perceived has potential to dominate or exploit others. Those in positions of authority control subordinates, so power implicitly states super ordination and subordination. In structures that put pressure on conflicting groups, the categories of authority work in an imperatively coordinated association (Dahrendorf., 1959). Based on that discussion, he divides the group type into three, namely the quasi group (the group that has the highest position and has the same interests), interest groups (part of a quasi-group that performs the task to fulfill the interests), and the conflict group (the group involved in conflicts and ruled by power) (Dahrenderof., 1959).

Dahrenderof equips and expands Marx's views by keeping abreast of historical-empirical facts that continue to be dynamic. According to him, social relations is not merely based on production, but also on the distribution of authority and authority over the capital in a social structure, especially to the Industrial Society (Dahrenderof., 1957, Abercrombie et al., 2010). He says that if we want to analyze conflict, then we must use conflict theory; but if we want to analyze order in a social system, we must use a functionalist perspective (Ritzer., 2010). It made him criticized, for his concepts of association, position, and role led to his theory of conflict closer to the theory of structural functionalism (Ritzer., 2010).

Unlike other sociologists, Randall Collins creates a more integrative conflict theory (Ritzer., 2010). The principles of conflict theory are the causal dimensions of modification of Marx, Weber, Durkheim, Mead, and Goffman (Collins., 1974). He did not develop conflict theory based on political views. He considers conflict as a central process in social life. In the context of conflict, if other sociologists assume that the individual is "forced" by the social structure as an external force, he considers that the pattern of individual interaction is the essence of social structure. According to him, the social structure as part of social stratification can be reduced to patterns of interaction of some individuals. "In any social interaction, we must look for the actual patterns of interaction between individuals, the resources available to individuals in different positions, and how these variables (work, education, ethnicity, age, and sex) influence their dominance to improve their personal status. Ideas and beliefs of individuals in different positions emerge as a personal ideology, to continue their dominance" (Collins., 1974: 61). In other words, for him, conflict can be seen based on patterns of interaction between individuals, resources owned by individuals, and the dominance between individuals on a social structure in a social stratification. In this context, the meaning of this "social structure" and "social stratification" still refers to a macro perspective. The meaning of "individual resources" and "patterns of interaction 
between individuals" refers to a micro perspective, which is related to a macro perspective (social structure and stratification). Thus, he seeks to integrate the two perspectives in his conflict theory (micro and macro).

Collins develops some general principles in analyzing conflicts, that is: 1) Conflict must come from real life, not derived from abstract formulas; 2) Analysis of conflicts are based on material factors, such as communications, equipment, needs, places, arms supply, and ways to display the impression; 3) Resource-clustered groups will be seeking for profit and oppressed groups with little resources; 4) Conflict analysis should take account of cultural phenomena such as ideas and beliefs. Also, must pay attention to the perspective of the group on the interests, resources, and power. A resource-rich group will force the idea to a group with few resources; 5) Compare empirical conflict cases, and then test the hypothesis by looking at the cases in different circumstances. Think in causality, and then generalize. The factors behind the conflict are complicated (Collins., 1974, Ritzer., 2010). Therefore, using these principles, the following section will critically scrutinize the conflict on the communal land ownership conflict or Gening Nura Newa in Lewobunga and Lewonara villages.

\section{Methodology}

This is qualitative research supplemented by deep interviews with some local actors. The collected data has been analyzed though interpretation or hermeneutic approaches, mainly reproductive hermeneutics that was developed by Wilhelm C.H Dilthey. ${ }^{1}$ At the same time, the Collins (1988) five principles of conflict is obviously useful due to more integrative compared to other theories.

\section{Communal Land Ownership Conflict between Lewobunga and Lewonara Villages}

All the people of East Nusa Tenggara, including the Adonara people, still hold strongly the local cultural elements. Several different tribes occupy each village in Adonara. The communal land has occurred in the border of the village of Lewobunga and the village of Lewonara. Land ownership claims are departed from the oral stories submitted by ancestors from generation to generation. The story versions of several tribes representing the two villages are different. Consequently, the ownership of communal land claimed by both villages simultaneously as the main source of the conflict between the two villages.

One of the impacts of conflict is realization through tribal warfare carried out by both villages. The war occurs for several reasons under customary law, namely: 1) Defense of the dignity of women; 2) Vengeance; 3) Defense of the ownership. The first and second reasons are often resolved peacefully through dialogue. However, the third reason always creates tribal warfare. Before the war begins, the soldier usually will conduct a ritual by eating red ginger given the chief of the tribe. After that, they will start to fight. The war took place between 6 am and $9 \mathrm{pm}$ and from $3 \mathrm{pm}$ to $8 \mathrm{pm}$. Interestingly the period between 9 am to $3 \mathrm{pm}$ is a break session. According to the customary law, while the war was paused during break session, it means there were more victims.

Lewobunga and Lewonara villages have involved nine period of wars such as 1912, 1933, 1947, 1958, 1972, 1978, 1996, 2012, and 2015 (Protomalayans., 2012). In 1960, the government issued a decree that the 15 hectares of the communal land was belonged to the village of Lewobunga. However,

\footnotetext{
${ }^{1}$ Reproductive Hermeneutics puts the process of understanding as a scientific method. The principal idea of Reproductive Hermeneutics is that researchers in the social sciences and humanities understand (Verstehen) the social-historical world through 're-experiencing back' (Nacherleben) or 'the motion of its expression; (Ausdruck) in documents, artifacts, symbol systems, etc., for total comperehention of data and context interpretation based on its meaning. For further discussion please see Bulhof (1980) and F. B. Hardiman (2015).
} 
according to Lewonara villagers, they are customarily claim as the communal land ownership. This situation has absolutely made the conflict sustained and the villagers continue to attack with each other involved in the tribal war. The following table briefly describes the tribal war in 2012 and 2015.

Table 1 The chronology of tribal warfare in 2012 and 2015

\begin{tabular}{|c|c|c|c|}
\hline No. & Duration & The beginning & Effect \\
\hline 1 & $\begin{array}{l}2 \text { October } 2012 \\
\text { to } 13 \text { November } \\
2012\end{array}$ & $\begin{array}{l}\text { Villagers of Lewonara } \\
\text { attacked Lewobunga } \\
\text { villagers living near the } \\
\text { communal land. The } \\
\text { villagers of Lewobunga } \\
\text { retaliated against the } \\
\text { villagers of Lewonara who } \\
\text { will do the traditional } \\
\text { ceremony }\end{array}$ & $\begin{array}{l}\text { - Two Lewonaraman } \\
\text { were killed } \\
\text { - } 23 \text { residents of both } \\
\text { villages were injured } \\
\text { - Houses, warehouses, } \\
\text { huts, cars, trucks, and } \\
\text { motorcycles } \\
\text { belonging to villagers } \\
\text { were burned }\end{array}$ \\
\hline 2 & $\begin{array}{l}\text { October 19, } \\
2015, \text { and } \\
\text { November 13, } \\
2015\end{array}$ & $\begin{array}{l}\text { Lewobunga villagers } \\
\text { attacked the villagers of } \\
\text { Lewonara. Then the villagers } \\
\text { of Lewobunga retaliated } \\
\text { against the village of } \\
\text { Lewonara }\end{array}$ & $\begin{array}{l}\text { - One Lewobunga man } \\
\text { died } \\
\text { - One Lewonara man } \\
\text { was injured } \\
\text { - One cottage belongs } \\
\text { to the villagers of } \\
\text { Lewonara was burned }\end{array}$ \\
\hline
\end{tabular}

Source: Adopted and modified from newspapers

In addition, there is the unique fact that no murder or fighting clash between the two villages outside the arena of war. Furthermore, some residents of the two villages still have a kinship due to the marriage's activities between several residents of the two villages. However, in the last five years, peoples of both villages hold each other's grudge-related conflict (Pos Kupang., 2015). The peace mediation efforts for both villages continue to be undertaken by local governments, religious leaders, army, and police in 2012 and 2015 (Kompas., 2012; Media Center., 2015). However, there are some obstacles during the conflict resolution because, on one hand, the villagers of Lewobunga want to resolve the conflict through the civil law (court), while the villagers of Lewonara want to solve it via customarily lawa (oral tradition and ritual) on the other hand (Pos Kupang., 2015). At the same time, they were involved a tribal war and have charged under a customary law. The villagers of both places continue to assemble homemade weapons, spears, machetes, etc., to supply the "troops" in the battlefield, even though the police have conducted a military raid (Pos Kupang., 2015). Until recently, there is no notion that the conflict will end, instead the conflict tends to occur repeatedly.

\section{The Complexity of the Conflict}

The complexity of the conflict pertaining communal land ownership in Lewonara and Lewobunga Indonesia is due to the political interest between the two villages. In addition, there is a serious resistance among the peoples especially regarding the role of local wisdom and civil law enforcement. The first principle of conflict analysis illustrates that the communal land conflict is an existing empirical phenomenon and has occurred for nine times on Adonara Island. Based on the second principle of analysis: 1) The information from interviews with a villager of Lewonara is that Lewobunga villagers are 
still afraid to travel to ports in Waiwerang City ${ }^{2}$ through a highway in the village of Lewonara. ${ }^{3}$ This shows communication between the two villagers is not well established and there is still grudge and distance. However, communication between the people of two villages that still have a kinship relationship took place well; 2) In this case, the need of the people of these two villages is full ownership of communal land. The weapons used during the conflict, both sharp weapons and homemade weapons, continue to be made or obtained illegally, even though the police continues to raid it; 3) The impressions displayed by the villagers on journalists, police, local government, etc., aim to keep up claims to the communal land: villagers of Lewobunga want to resolve conflicts through courts; the villagers of Lewonara want to solve it customarily. This is reinforced by interviews with a Lewobungaman that Lewobunga villagers always convey to journalists and police to resolve conflicts through the court; ${ }^{4} 4$ ) Based on the venue, residents of both villages live in adjacent locations. The communal land as a base of conflict lies on the border between the two villages. This can affect the vulnerability of the conflict. Thus, the first and second principles apply empirically.

Based on the third principle, without computing the communal land as a resource, the ownership of both villagers towards other resources (gardens, private land, wages, etc.) is relatively balanced, because the villagers of both villages work as farmers and ranchers (Protomalayans., 2012). In addition, most villagers of the two villages have lower education background (elementary school and junior high school). Some villagers never even received formal education or attended school. With the balance of ownership of these resources, there is no suppression (super ordination) from one of the parties with the most resources. Villagers of both villages continue to claim the communal land and wage war. Thus, this third principle does not apply empirically.

Based on the fourth principle, the visible cultural phenomenon is the implementation of customary laws that legalize tribal warfare to make sure full ownership of communal land. One of the principles of customary law is "Koda mur'eng de'ino, Koda nalang gokano" which means, "win for the right, and lose by the wrong." In other words, in the tribal war, the winning village is considered as right by custom. The losing village is perceived as the wrong party for committing an offense. In the perspective of resources, resources owned by villagers (gardens, private land, wages, etc.) are the same, so there is no coercion of ideas from one of the most resourceful parties. In the perspective of power and interests, the communal land as a resource is a key point. For a long time, agricultural products, such as coconuts and cocoyam, grew on the communal land. As farmers and ranchers, the land, including the communal land, is an important economic-cultural capital; since land can be managed to generate wages. If one village succeeds to have the communal land fully, the villagers can be free to farm and garden on the communal land; to manage coconuts and cocoyam that have grown in the communal land. In other words, full ownership of communal land is a form of power and interest in communal land itself, which in turn can generate extra wages for the villagers and improve their social status. However, until now Lewonara and Lewobunga villagers do not have this communal land fully, for one thing: the claim of Lewobunga village over the ownership of communal land is based on the court's verdict while the claim of Lewonara village is based on customary law. No village has succumbed. Conflict is settled through tribal warfare to ensure full ownership. However, there is no village really winning because the police and the army always interrupt the ongoing war. However, tribal warfare has the possibility of re-occurring in the future, because there is 'no winner, no full ownership'. Thus, in general, this fourth principle applies empirically. However, in particular, one sub principle of fourth principle, namely, "those with multiple resources will impose their ideas on those with few resources", does not apply. Causality, this sub principle should be the part of the third principle.

\footnotetext{
${ }^{2}$ Waiwerang is the only city in Adonara Island

${ }^{3}$ Interview on Sunday, April 9th, 2017

${ }^{4}$ Interview on Wednesday, March 22nd, 2017
} 
In applying the fifth principle, the conflict between Lewobunga and Lewonara villages will be compared with other research on land ownership conflicts in two other districts on Flores Island. In Clark (2004) for instance have conducted a research funded by the World Bank at several villages in District of Manggarai and Sikka. In general, the results of the study illustrate that ownership conflicts occur due to the problem of land boundaries and unclear land ownership certificates. These conflicts are resolved through mediation efforts and court decisions. For comparison as well as differences, these conflicts do not cause death and material loss. In the past five years, the conflict between Lewobunga and Lewonara villages has resulted in three deaths and many material losses and has a pattern of historical violence (there have been deaths and material losses during nine wars since 1912). In general, the main trigger of conflict between Lewobunga and Lewonara villages is that both villagers have a strong ambition to control the communal land. This conflict can potentially explosive because the local government, religious leader, police, and army only conducted mediation once the conflict occurred. As consequence, the mediation tend to aborted and not sustain. Thus, based on that description, the fifth principle empirically proven.

\section{Critical Reconstruction: Wild Zone and No Winners Party}

Based on the discussion and the results of the analysis, the third principle and the one sub principle of fourth principle of Collins's conflict analysis principles that are not applicable will be criticized (reconstructed) in Figure 1.

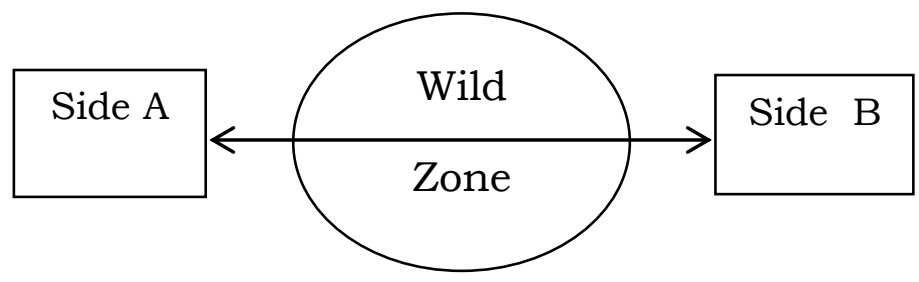

Fig. 1 Wild zone, no winners party (the double arrow signifies two parties claim the wild zone for each other)

Source: personal observation

Based on the above figure, there are two points as the reconstruction effort, namely The Wild Zone and The No Winners Party. These two important points apply to the phenomenon of the communal land ownership conflict in the villages of Lewonara and Lewobunga. The details are as the following sections.

\section{The Wild Zone}

In a conflict, there is a wild zone which is a place that is only mutually claimed and contested by two opposing parties. Empirical explanation: The communal land is a wild zone. Only Lewobunga and Lewonara villages claimed ownership of the commnal land. Both villages are involved in the tribal war to seize and control the land. 


\section{The No Winners Party}

In a conflict, there are parties without a winner consisting of two opposing parties who claim one another and fight over wild zones. In the struggle for this wild zone, the two parties have balanced resources. This balance of resources makes two parties oppress one another and impose their ideas on one another. The presence of third parties who have the most resources are unable to reconcile the two parties and are unable to find the right solution. Empirical explanation: The villages of Lewobunga and Lewonara are two opposing parties claiming each other's wild zone and fighting wild zones through tribal warfare. Both villages have balanced resources, so the two villages continue to fight and force each other to recognize claims of wild zone ownership. The presence of a third party that has many resources, such as the government, religious leaders, police, and army, is unable to reconcile the villagers of both villages and is unable to find the right solution (fair and sustainable).

Thus, these two important points, The Wild Zone and The No Winning Party, are critical reconstruction of Collins's one sub-principle and one principle of conflict analysis that are not applicable in the communal land ownership conflict in Lewobunga and Lewonara villages.

\section{Conclusion}

Theories of western sociology, especially the sociology of conflict, continue to evolve from the past until now. Western sociologists continue to research, criticize, complement, extend the old theories, and even build new theories. But, not all theories of western sociology can fully explain phenomena in countries with diverse traditional cultures. This is proven by the third principle and the fourth subprinciple of Collins conflict analysis which are not applicable in Indonesia, particularly in explaining the conflict of ownership of communal land that caused the tribal war between Lewobunga and Lewonara villages.

The invalid principle is "the resourceful party will oppress the person with few resources". An invalid sub-principle is "the resource-holder will impose his idea on a person with few resources". The tribal warfare that took place could not be analyzed using these principle and sub-principle. Therefore, this critique and critical reconstruction of the invalid principle include two important points, namely The Wild Zone and The No Winners Party. These two important points are not positivistic and applicable in the two villages.

\section{References}

Ambercrombie, N., Hill, S., Turner, B. S. (2010). Kamus Sosiologi [Dictionary of Sociology]. Yogyakarta: Pustaka Pelajar.

Antara News. (2015). Delapan Rumah dibakar dalam Perang Tanding di Adonara [eighth house were burned during a clash in Adonara]. Retrieved from http://cimg.antaranews.com/ makassar.

Bottomore, T. (1991). Class Conflict. In Bottomore, T. (Eds), A Dictionary of Marxist Thought. Oxford: Blackwell Publishers Ltd.

Bulhof, I.N. (1980). Wilhelm Dilthey: A Hermeneutic Approach to the Study of History and Culture. The Hague: Springer Netherlands. 
Clark, S. (2004). More than just Ownership: Ten Land and Natural Resource Conflict Case Studies from East Java and Flores. Jakarta: World Bank Office Jakarta.

Collins, R. (1988). The Durkheimian Tradition in Conflict Sociology." In Alexander, J.C. (Ed), Durkheimian Sociology: Cultural Studies. Cambridge: University Press.

Dahrenderof, R. (1959). Class and Class Conflict in Industrial Society. Standford: Standford University Press.

F. B. Hardiman. (2015). Seni Memahami: Hermeneutik dari Schleiermacher sampai Derrida [The Art of Understanding: The Hermeneutics from Schleiermacher to Derrida]. Yogyakarta: Penerbit Kanisius.

Flores Bangkit. (2015). Masyarakat Lewobunga Adonara Mengadu Ke Kapolda NTT [Lewobunga Adonara Community Complains to the NTT Police Chief]. Retrieved from http://floresbangkit.com /2015/06/masyarakat-lewobunga-adonara-mengadu-ke-kapolda-ntt/.

Kompas. (2012). Peta Asli Batas Tanah Harus Ditunjukkan [Original Map of Soil Bounding Should Be Displayed]. Retrieved from http://regional.kompas.com/read/2012/10/08/0316360/Peta.Asli.Batas. Tanah.Harus.Ditunjukkan.

Media Center. (2015). Bentrok 13 dan 14 November 2012: Desa Lewonara dan Lewobunga di Adonara, Flores Timur, NTT [The Clash of 13 and 14 November 2012: Lewonara and Lewobunga Villages in Adonara, East Flores, NTT]. Retrieved from http://www.mediacenter.or.id.

O’Neil, N. (1985). Marxism and Psychology. In Shaw, M. (Ed), Marxist Sociology Revisited: Critical Assessment. London: The Macmillan Press.

Pos Kupang. (2012). Ini Korban Luka Bentrokan di Adonara [List of Victims of Adonara Clash]. Retrieved from http://lewobunga.blogspot.co.id/20130501archive.html.

Pos Kupang. (2015). Ibarat Api dalam Sekam, Lewonara dan Lewobunga kembali bergejolak [Like the Fire in the Chaff, Lewonara and Lewobunga Re-Clash]. Retrieved from http://kupang.tribunnews.com/amp/2015/05/24/ibarat-api-dalam-sekam-lewonara-lewobunga-kembalibergejolak.

Protomalayans. (2012). Suku Lewobunga dan Suku Lewonara [Lewobunga and Lewonara Tribes]. Retrieved from http://protomalayans.blogspot.co.id/2012 /11/suku-lewobunga-dan-suku-lewonaranusa.html.

Ritzer, G. (2010). Sociological Theory ( $8^{\text {th }}$ Edition). New York: McGraw-Hill.

Shaw, M. (1985). Marxism, The State and Politics. In Shaw, M. (Ed), Marxist Sociology Revisited: Critical Assessment. London: The Macmillan Press.

Simmel, G. (1955). Conflict and The Web of Group-Affiliations. New York: The Free Press.

Thompson, K. (2002). Emile Durkheim (Key Sociologists). London: Routledge.

Weber, M. (1947). The Theory of Social and Economic Organization. Translated by Talcott Parsons dan A.M Handerson. New York: Oxford University Press. 
Wieviorka, M. (2010). Social Conflict. France: l'Ecole des Hautes Etudesen Sciences Sociales. Retrived from http://csi.sagepub.com/content/61/56/696. full .pdf.

Wright, E.O. (2003). Social Class. Madison: Department of Sociology University of Wisconsin. Retrieved from https://www.ssc.wisc.edu/wright/social\%20class \%20--\%20sage.pdf.

\section{Copyrights}

Copyright for this article is retained by the author(s), with first publication rights granted to the journal.

This is an open-access article distributed under the terms and conditions of the Creative Commons Attribution license (http://creativecommons.org/licenses/by/4.0/). 